\title{
Perceptions on Competence by Design in urology
}

Peter (Zhan Tao) Wang ${ }^{1}$; Ernest Chan ${ }^{1}$; Adam Forster ${ }^{2}$; Jennifer Vergel De Dios ${ }^{3}$; Alp Sener ${ }^{1,4}$; Sumit Dave ${ }^{1,5}$; Saad Chahine ${ }^{6}$

${ }^{1}$ Department of Surgery, Division of Urology, Western University, London, ON, Canada; ${ }^{2}$ Schulich School of Medicine \& Dentistry, Western University, London, ON, Canada; ${ }^{3}$ Department of Anesthesiology, Western University, London, ON, Canada; ${ }^{4}$ Department of Microbiology and Immunology, Western University, London, ON, Canada; ${ }^{5}$ Department of Pediatrics, Western University, London, ON, Canada; ${ }^{6}$ Department of Medicine, Faculty of Education, Western University, London, ON, Canada

Cite as: Can Urol Assoc J 2018 November 20; Epub ahead of print. http://dx.doi.org/10.5489/cuaj.5610

Published online November 20, 2018

$* * *$

\section{Abstract}

Introduction: The Royal College of Physicians and Surgeons of Canada has begun implementing Competence by Design (CBD). However, it is unclear how much urology trainees and faculty know about CBD, their attitudes towards this change, and their willingness to embrace and participate in this new model of training.

Methods: This cross-sectional study was conducted through an online survey, which was administered to all trainees and faculty at Canadian urology programs prior to the implementation of CBD. The final survey consisted of eight demographic questions, 17 fivepoint Likert items, one visual analog scale question, 11 multiple selection questions, and two open-ended questions.

Results: A total of 74 participants (38 faculty and 36 trainees) across 12 universities responded, with a completion rate of $82.4 \%$. This corresponded to an overall response rate of $20.5 \%$. Overall, there was a lack of resounding enthusiasm towards this shift to CBD in urology. Although both trainees and faculty had overall positive perceptions of CBD on assessment, teaching, and readiness, most agreed that this transition will be costly and associated with increased requirements for time, funding, and administrative support. Furthermore, there were significant concerns regarding the lack of valid assessment tools and evidence for the validity of entrustable professional activities.

Conclusions: While this survey has demonstrated an appreciation for the benefits of CBD, challenges are equally anticipated. CBD in urology will be a fertile research area; this study has identified several important educational questions regarding the model's effectiveness and consequences, thus, providing collaborative opportunities among all Canadian programs. 


\section{Introduction}

Introducing competency-based medical education (CBME) without understanding readiness for program transition may be detrimental to its successful implementation. Globally, training programs are embarking on this major transformation by moving away from the "time-based" model of postgraduate medical education and instead focusing on the process of attaining competence on key expectations of the profession. ${ }^{1,2}$

The Royal College of Physicians and Surgeons of Canada (RCPSC) has begun implementing a customized version of this learner-centered, outcomes-based approach to training and assessment called Competence by Design (CBD). This approach to training is fits within the Canadian context, and is proposed to be more flexible, accountable, and adaptable. ${ }^{3,4}$ Using a staged rollout, the process has already started in urology as of July 2018. However, it is unclear how much urology trainees and faculty know about CBD, their attitudes towards this change in medical pedagogy, and their willingness to embrace and participate in this new model of medical training.

\section{Literature review}

Little is known about the readiness of programs embarking on a CBD transformation. ${ }^{5}$ Interviews with Canadian program directors and residents in anesthesiology prior to the implementation of CBD indicated a variety of perceived challenges, including increased burden on program administration, implications for trainees, and ambiguity regarding "competence" and how evaluation will be performed. ${ }^{6}$ Similar findings were demonstrated by Mann et al. in a preliminary study of residents on their perceptions of CBD. ${ }^{7}$ In the United States, members of the Residency Review Committee for Urology ${ }^{8}$ highlighted the paucity of effective evaluation tools and lack of evidence that these changes will ultimately improve the training of residents. Despite these uncertainties, all urology residency training programs will be making the transition to CBD.

Competence by Design refines how educators and trainees interact and work together. Specifically, CBD involves generating a new approach to trainee evaluation through developing and implementing tools that focus on meeting milestones. There is also a focus on creating a learner-centered curriculum, with emphasis on objective trainee competency as a necessity for graduation. ${ }^{9}$ Competency is achieved by meeting proficiency in required entrustable professional activities (EPAs) prior to the conclusion of training. Entrustable professional activities are the fundamental units of training that are required for unsupervised practice in each program, developed by consensus agreements within specialty working groups for that program.

Some have challenged the comprehensiveness of EPAs to act as a representation of physician competency. Inconsistencies also exist in the decisions surrounding which EPAs should be assessed, how the milestones (subunits of EPAs) ought to be evaluated, and how many times a trainee needs to be evaluated on an EPA to be deemed competent. This lack of agreement coupled with unfamiliarity about CBD may result in "logistical chaos." 
Furthermore, some authors have postulated that an EPA-centric curriculum would remove important clinical experiences deemed unnecessary to achieve competence, creating a utilitarian approach to the trainee. ${ }^{9}$ However, our current experience is unknown, and these uncertainties undocumented.

\section{Objectives}

In this study, we seek to compare the perceptions and attitudes of trainees (residents/fellows) and faculty towards CBD within urology, as well as identify perceived benefits and challenges of this transition.

\section{Methods}

Institutional ethical approval was obtained (IRB\#111397). This cross-sectional study was conducted through an online survey (Qualtrics) comprising both qualitative and quantitativelybased items. The survey was administered to all trainees and faculty at Canadian urology programs in April 2018, with all data collected prior to the implementation of CBD in July 2018.

\section{Survey design}

The survey was designed to evaluate five constructs related to CBD: teaching, assessment, institutional readiness, influences on academic/clinical practice, and time commitment. An extensive list of survey items was developed by three educators using brainstorming sessions and literature review (PW, SC, and JV).

Survey items were then reviewed by five urology faculty at Schulich School of Medicine \& Dentistry. These experts rated items from 1-10 (10 = very important). Items that were rated 7 or higher were kept for the final survey, while items rated 4 or below were removed. Items rated 5-6 were modified, retained, or removed based on expert opinion.

The final survey consisted of eight demographic questions, seventeen 5-point Likert items (5=Strongly Agree, 1=Strongly Disagree), one visual analog scale (VAS) question, eleven multiple selection questions, and two open-ended questions (Appendix). All but the open-ended questions were required for the completion of the survey. The multiple selection questions elicited binary responses (agree/disagree) on benefits (26 items) and challenges (27 items) of CBD described by previous qualitative studies and the RCPSC. ${ }^{2,6,10}$

\section{Participant recruitment}

Trainees and faculty from 12 Canadian urology programs were electronically solicited to participate in the study. Participants were provided with an anonymous link to the survey. Participation was voluntary with submission of the survey implying consent. All potential participants were invited to respond within 1 month with a reminder sent 4 weeks afterwards. 


\section{Statistical analysis}

Descriptive statistics were performed on the demographic data. Prior to comparative analyses, Cronbach's alphas were computed to investigate the reliability of the constructs used to design the survey and to provide evidence supporting valid interpretations. The Kuder-Richardson 20 (KR-20) reliability index was used to estimate internal consistency within the perceived benefits and challenges.

Perceptions of the five constructs, as well as the perceived benefits and challenges between faculty and trainees were compared using independent samples t-tests with Bonferroni corrections applied. Statistical analyses were conducted using SPSS (version 25, IBM) and Iteman (http://www.assess.com/iteman/).

\section{Qualitative analysis}

A general thematic analysis was used to determine patterns of responses to open-ended questions. Each response was reviewed and thematically coded by two research team members (AF and EC). The team met after the initial coding to refine the themes. Themes were then reviewed once more for final confirmation. The most common themes identified are presented in this paper with representative quotes.

\section{Results}

A total of 74 participants (38 faculty and 36 trainees) responded with a completion rate of $82.4 \%$. This corresponds to a response rate of 20.2\% among academic Urology faculty and 20.8\% among Urology trainees (20.5\% response rate overall). Of the faculty, 27 (71.1\%) were Residency Training Committee (RTC) members. Tables 1A/B summarizes the distribution of the trainees by PGY year and faculty by years in practice.

Overall, there were no significant differences between trainees and faculty in terms of favorability of CBD $(6.0 \pm 2.1$ versus $5.0 \pm 2.5, \mathrm{p}=0.91)$, such that both groups did not have overtly positive or negative favorability towards the implementation of CBD. Among faculty, 24 (64.9\%) believed that their program was ready for CBD.

\section{Perceptions}

Four of the five constructs were made up of multiple items, while time commitment was summarized in one item. The four multi-item constructs analyzed are summarized in Supplementary Table 1. Overall, the four multi-item constructs had high internal consistency: teaching ( $\alpha=0.87$ ), assessment ( $\alpha=0.83$ ), readiness ( $\alpha=0.81)$, and influence $(\alpha=0.87)$.

Table 2 summarizes the comparison of CBD perceptions between faculty and trainees. Specifically, there were no significant differences between faculty and trainees with regard to their perceptions of assessment, teaching, and readiness; both groups had overall positive perceptions towards these constructs. For example, both faculty and trainees perceived a benefit 
on the assessment of trainees, which included improved quality of feedback and ability to identify specific areas of weakness (faculty $3.82 \pm 0.90$ versus trainees $3.83 \pm 0.66, p=0.865$ ).

While both groups agreed CBD would increase the time commitment required of faculty, there was a significant difference in the strength of agreement ( $4.57 \pm 0.56$ versus $4.00 \pm 0.89, \mathrm{p}=$ 0.002). However, more faculty perceived a negative influence of CBD on their clinical or academic practice, whereas trainees demonstrated an overall neutral stance on this construct ( $2.57 \pm 0.81$ versus $3.15 \pm 0.91, \mathrm{p}=0.006)$.

\section{Benefits and challenges}

There was high internal consistency for the benefit (KR-20 $=0.94)$ and challenge (KR-20 $=0.94)$ items on the multiple selection questions. Overall, participants agreed on $46 \%$ of the 26 benefit items. Similarly, participants agreed on $46 \%$ of the challenges. The correlation was moderate $(r=0.52)$, suggesting those who perceived more benefits also perceived more challenges.

The perceived benefits are summarized in Table 3 . The most common benefit perceived by both groups was an improved ability to identify specific areas of weakness, although a significantly higher proportion of trainees perceived this to be a benefit compared to faculty (97.1\% versus $74.2 \%, \mathrm{p}=0.026)$.

The most prevalent theme among the top benefits related to assessment and feedback (8/10). The last two items related to improved accountability and transparency in resident training. Surprisingly, the role of a competency committee was not globally perceived as a benefit. Similarly, most respondents did not view CBD as being beneficial to patient care, resident wellness, or the transitions between medical school, residency and independent practice.

Table 4 highlights the top challenges perceived by the participants. There were no statistical differences in the responses between the two groups. The top 6 challenges were related to increases in the resources required for the implementation of CBD (time, cost, and administrative support) and the subsequent impact on clinical practice.

The last 4 challenges described concerns regarding 'process' items of CBD including the lack of valid assessment tools, difficulties in achieving rare EPAs, unequal distribution of evaluations amongst faculty ('gaming' the system by trainees) and remediation in the form of individualized learning programs. Items relating to number of common cases, resident competition and scheduling, as well as impacts on future fellowship and employment were not viewed as significant challenges.

Qualitative analysis

The common themes identified from the qualitative analysis were similar to our quantitative results. Representative quotes are included in Supplementary Table 2 to exemplify the emotional tone of the responses. 
When the respondents were asked to comment on their greatest concern regarding this transition into CBD, two common themes were identified: burden and lack of evidence. Overall, burden was the most prevalent theme and created the greatest degree of concordance between faculty and trainee. There is particular emphasis on time commitment required to complete EPAs meaningfully and a general paucity of preparedness at an administrative level. In addition, there was a collective concern regarding the unintended consequences of this increased burden on faculty, residents and patient care. The theme relating to the lack of evidence centered on EPAs as appropriate targets for resident competency, leading to a broader lack of confidence towards $\mathrm{CBD}$ as an effective way to structure a residency program.

This thematic analysis also identified two common benefits from the respondents: early identification and teaching/feedback. Unsurprisingly, the theme of identifying trainees with specific or global deficiency was common amongst the respondents. However, the general conviction and tone regarding this benefit were irresolute. Furthermore, there was a perception that $\mathrm{CBD}$ could foster consistent and continuous improvement among trainees through improved teaching resulting from regular feedback and well-defined targets.

\section{Discussion}

The RCPSC's CBD initiative branched from the recommendations by the Future of Medical Education in Canada Postgraduate Project (FMEC PG). ${ }^{1}$ The rationale behind this shift towards $\mathrm{CBD}$ is that responsible medical education involves systematic deliberation (i.e., designing) of a learner's journey throughout their entire career. ${ }^{11}$ Through CBD, this is achieved by training learners based on competencies that are required by an independently practicing healthcare professional. This is facilitated through discipline-specific assessment, increased emphasis on direct and indirect observation, and provision of timely, constructive, and specific feedback., ${ }^{42}$

By focusing on the development of competence through EPAs, CBD shifts the focus of residency to learning as opposed to time spent in training. This is thought to ensure competence, support development of skills and abilities throughout practice, address gaps in training, increase accountability, and promote transparency in resident training. ${ }^{4}$ Such needs in urology have previously been described by Morrison and MacNeily ${ }^{13}$, who indicated that many specialized clinical areas of urology required increased emphasis, as well as a need for preparing residents in their transition to independent practice.

In this study, we found a general sense of uncertainty and neutral favorability toward $\mathrm{CBD}$ amongst urologists and urology trainees in Canada. The perceived benefits of CBD are self-evident. Both faculty and trainees agreed that improved assessment and feedback were the overarching hallmark of this training model, with a specific focus on the ability to identify specific areas of weakness. These findings correlate well with previous qualitative studies. ${ }^{6,7}$ However, when discussing this benefit, Boet et al. cautions us that one must also note and understand the ambiguity surrounding definitions of 'competence'. 6 
Competency, as defined by the RCPSC, is "an observable ability of a health professional to integrate multiple components such as knowledge, skills, values, and attitudes. Since competencies are observable, they can be measured and assessed to ensure their acquisition. Competencies can be assembled like building blocks to facilitate progressive development”, 2,9,12 However, the competencies of surgeons also include technical skills, which do not have a predefined gold standard.

Furthermore, these benefits are grounded on the assumption that providing routine evaluation and feedback improves learning. However, this also assumes that we have valid and effective evaluation tools for our EPAs. This may not be the case, as lack of valid assessment tools was perceived to be a common challenge among urologists. This limitation is further compounded by the variability in the development of assessment tools across the different programs in Canada, as well as the pseudo-requirement of basing these tools on the O-score, which was validated on a population of orthopedic and general surgery residents. ${ }^{14}$

Similar concerns were found regarding the accuracy of EPAs in our qualitative analyses. Apramian et al. described how different surgeons had divergent views on whether or not certain procedural steps were principles versus preferences for the same surgery. ${ }^{15,16}$ If the success of CBD is predicated on the accurate measurement of competence and constructs of EPAs, then this discordance further muddies the potential benefit of CBD.

The challenges demonstrated in this study were similar to previous studies, citing increased resource allocation as a major deterrent to the implementation of CBD. This challenge includes both the increased financial and administrative burden placed on Canadian programs. Overall, $80 \%$ of participants perceive a detrimental effect on the day-to-day clinical practice of faculty due to $\mathrm{CBD}$. In addition, there were concerns regarding 'gaming' or choosing 'easy' evaluators by trainees and whether this would unevenly distribute the burden of assessment.

These perceived challenges provide insight into important educational questions: What are the unintended consequences of this implementation moving forward? How will the increased frequency of assessment affect the emotional well-being of the trainees and faculty? How will trainee or faculty fatigue affect the accuracy of these assessments? Certain parallels may be drawn from the frequent high-stakes 'testing' of the "No Child Left Behind" initiative in the United States. A survey conducted by Jones et al. showed that $48.5 \%$ of teachers felt frequent high-stakes testing had a negative impact on students' "love of learning” and 61\% percent felt their students were more anxious because of it. ${ }^{17}$ Educator 'burn-out' due to this initiative has also been described. ${ }^{18}$

\section{Limitations}

The interpretation of this study is limited by the biases inherent to a relatively small response rate and study population. Furthermore, a French language version of this survey was not available, which may have reduced our response rates. In addition, given the 'fait acompli' of CBD implementation, the responses to this survey may be different if this study was performed prior 
to the decision of implementing CBD. Lastly, the current trainees taking part in this survey are unaffected by the process, as CBD is only relevant and instituted for new PGY1s.

Although this is the first study to uniformly survey both faculty and trainees of a subspecialty surgical program, these findings may not be generalizable to non-surgical programs. However, the findings of this survey may provide important insight to other surgical programs due for CBD implementation in the coming years.

\section{Conclusion}

Overall, this study has shown a lack of resounding enthusiasm towards this shift to CBD in urology. Although both trainees and faculty had overall positive perceptions of CBD on assessment, teaching and readiness, most agreed that this transition will be costly and associated with increased requirements for time, funding, and administrative support. Furthermore, there were significant concerns regarding the lack of valid assessment tools and evidence for the validity of entrustable professional activities. Competence by Design in urology will be a fertile research area. This study has identified several important educational questions regarding the model's effectiveness and potential consequences, thus providing collaborative opportunities amongst all Canadian programs. 


\section{References}

1. Busing N, Harris K, MacLellan A-M, et al. The future of postgraduate medical education in Canada. Academic Medicine 2015;90:1258-63.

2. Harris K, Frank J. Competence by design: Reshaping Canadian medical education. Royal College of Physicians and Surgeons of Canada 2014.

3. Iobst WF, Sherbino J, Cate OT, et al. Competency-based medical education in postgraduate medical education. Medical teacher 2010;32:651-6.

4. Competence By Design. The Royal College of Physicans and Surgeons of Canada, 2017. (Accessed November 26, 2017, 2017, at http://www.royalcollege.ca/rcsite/cbd/competence-by-design-cbd-e.)

5. Van Melle E, Frank J, Brzeznia S, et al. Competency by Design-Residency Eucation: A framework for program evaluation. Ottawa, ON: Royal College of Physicians and Surgeons of Canada; 2017.

6. Boet S, Pigford A-AE, Naik VN. Program director and resident perspectives of a competency-based medical education anesthesia residency program in Canada: a needs assessment. Korean Journal of Medical Education 2016;28:157-68.

7. Mann S, Hastings A, Egan R. Resident Perceptions of Competency-Based Medical Education2016.

8. Kerfoot BP, Mitchell ME, Novick AC. Grappling with the evaluation of clinical competencies: a view from the Residency Review Committee for Urology. Urology 2002;60:223-4.

9. Frank JR, Snell LS, Cate OT, et al. Competency-based medical education: theory to practice. Medical teacher 2010;32:638-45.

10. Sonnadara RR, Mui C, McQueen S, et al. Reflections on Competency-Based Education and Training for Surgical Residents. Journal of Surgical Education 2014;71:151-8.

11. RCPSC. Competence by Design: What you need to know. A Resident's Guide. Ottawa, ON: Royal College of Physicians and Surgeons of Canada; 2017.

12. Holmboe ES, Sherbino J, Long DM, et al. The role of assessment in competency-based medical education. Medical teacher 2010;32:676-82.

13. Morrison KB, MacNeily AE. Core competencies in surgery: evaluating the goals of urology residency training in Canada. Canadian Journal of Surgery 2006;49:259-66.

14. Gofton WT, Dudek NL, Wood TJ, et al. The Ottawa surgical competency operating room evaluation (O-SCORE): a tool to assess surgical competence. Academic Medicine 2012;87:1401-7.

15. Apramian T, Cristancho S, Sener A, et al. How Do Thresholds of Principle and Preference Influence Surgeon Assessments of Learner Performance? Ann Surg 2018;268:385-90.

16. Apramian T, Cristancho S, Watling C, et al. Thresholds of Principle and Preference: Exploring Procedural Variation in Postgraduate Surgical Education. Acad Med 2015;90:S70-6.

17. Jones MG, Jones BD, Hardin B, et al. The impact of high-stakes testing on teachers and students in North Carolina. The Phi Delta Kappan 1999;81:199-203. 
18. Berryhill J, Linney JA, Fromewick J. The Effects of Education Accountability on Teachers: Are Policies Too-Stress Provoking for Their Own Good? International Journal of Education Policy and Leadership 2009;4:1-14. 
Figures and Tables

\begin{tabular}{|l|l|c|}
\hline Table 1A. Urology trainee distribution \\
\hline Trainee & PGY level & Number (\%) \\
\hline & 1 & $8(22.2)$ \\
\hline & 2 & $3(8.3)$ \\
\hline & 3 & $8(22.2)$ \\
\hline & 4 & $3(8.3)$ \\
\hline & 5 & $7(19.4)$ \\
\hline & Fellow & $7(19.4)$ \\
\hline
\end{tabular}

Table 1B. Urology faculty distribution

\begin{tabular}{|l|l|c|}
\hline Faculty & Years in practice & Number (\%) \\
\hline & $0-5$ years & $5(13.2)$ \\
\hline & $6-10$ years & $11(28.9)$ \\
\hline & $11-15$ years & $8(21.1)$ \\
\hline & $16-20$ years & $8(21.1)$ \\
\hline & $>20$ years & $6(15.8)$ \\
\hline
\end{tabular}

Table 2: Perceptions of CBD between faculty and trainees

\begin{tabular}{|l|c|c|c|}
\hline Construct & Faculty (n=38) & Resident/fellow (n=36) & \\
\hline & \multicolumn{2}{|c|}{ Mean \pm SD } & p \\
\hline Teaching & $3.40 \pm 0.86$ & $3.71 \pm 0.76$ & 0.107 \\
\hline Assessment & $3.82 \pm 0.90$ & $3.83 \pm 0.66$ & 0.865 \\
\hline Readiness & $3.66 \pm 0.86$ & $3.42 \pm 0.72$ & 0.254 \\
\hline Influence & $2.57 \pm 0.81$ & $3.15 \pm 0.91$ & 0.006 \\
\hline Time commitment & $4.57 \pm 0.56$ & $4.00 \pm 0.89$ & 0.002 \\
\hline
\end{tabular}

*Likert scale: 5 - Strongly agree and 1 - Strongly disagree. 


\begin{tabular}{|c|c|c|c|c|}
\hline Rank (\%) & Perceived benefits & Trainee (\%) & Faculty (\%) & $\mathbf{p}$ \\
\hline $1(86.2)$ & $\begin{array}{l}\text { Improve ability to identify specific } \\
\text { areas of weakness }\end{array}$ & 97.1 & 74.2 & 0.026 \\
\hline $2(83.1)$ & $\begin{array}{l}\text { Identification of residents who require } \\
\text { extra assistance }\end{array}$ & 91.2 & 74.2 & 0.141 \\
\hline $3(78.5)$ & More personalized feedback & 85.3 & 71.0 & 0.243 \\
\hline $4(76.2)$ & $\begin{array}{l}\text { Improve residents' knowledge of the } \\
\text { competencies they are expected to } \\
\text { achieve }\end{array}$ & 75.8 & 76.7 & 0.959 \\
\hline $5(76.2)$ & $\begin{array}{l}\text { Improve residents' awareness/clarity of } \\
\text { competency level that residents are } \\
\text { expected to attain }\end{array}$ & 75.8 & 76.7 & 0.447 \\
\hline $6(75.4)$ & Facilitate feedback delivery & 76.5 & 74.2 & 0.263 \\
\hline $7(75.4)$ & $\begin{array}{l}\text { Increase frequency of structured } \\
\text { feedback }\end{array}$ & 79.4 & 71.0 & 0.084 \\
\hline $8(75.4)$ & $\begin{array}{l}\text { Increase accountability of faculty for } \\
\text { resident education }\end{array}$ & 76.5 & 74.2 & 0.311 \\
\hline $9(64.6)$ & $\begin{array}{l}\text { Improve faculty awareness/clarity of } \\
\text { competency level that residents are } \\
\text { expected to attain }\end{array}$ & 64.7 & 64.5 & 0.175 \\
\hline $10(64.5)$ & $\begin{array}{l}\text { Promote transparency in residency } \\
\text { training }\end{array}$ & 68.8 & 60.0 & 0.769 \\
\hline
\end{tabular}

Rank is based on response from both faculty and trainee. 


\begin{tabular}{|c|c|c|c|c|}
\hline Rank (\%) & Perceived challenge & Trainee (\%) & Faculty (\%) & $\mathbf{p}$ \\
\hline $1(93.4)$ & $\begin{array}{l}\text { Increased administrative burden for } \\
\text { faculty }\end{array}$ & 90.3 & 96.7 & 0.513 \\
\hline $2(90.2)$ & $\begin{array}{l}\text { Increased administrative burden for } \\
\text { coordinators }\end{array}$ & 87.1 & 93.3 & 0.189 \\
\hline $3(88.5)$ & $\begin{array}{l}\text { Increased faculty time commitment to } \\
\text { teaching }\end{array}$ & 83.9 & 93.3 & 0.499 \\
\hline $4(88.5)$ & $\begin{array}{l}\text { Need for faculty commitment and } \\
\text { participation }\end{array}$ & 83.9 & 93.3 & 0.395 \\
\hline $5(80.3)$ & Increased burden on clinical practice & 80.3 & 80.0 & 0.111 \\
\hline $6(77.0)$ & $\begin{array}{l}\text { Increase expenses required for } \\
\text { implementation and maintenance of } \\
\text { CBD }\end{array}$ & 71.0 & 86.7 & 0.119 \\
\hline 7 (68.9) & $\begin{array}{l}\text { Lack of valid and reliable tool to } \\
\text { measure program-specific } \\
\text { competencies }\end{array}$ & 64.5 & 73.3 & 0.715 \\
\hline $8(67.2)$ & $\begin{array}{l}\text { Difficulty achieving competence in } \\
\text { entrustable professional activities } \\
\text { (EPAs) that occur uncommonly }\end{array}$ & & 70.0 & 0.398 \\
\hline $9(67.2)$ & $\begin{array}{l}\text { Promote selective evaluation by } \\
\text { residents (residents choose "easy" } \\
\text { evaluators) }\end{array}$ & 64.5 & 70.0 & 0.31 \\
\hline $10(65.6)$ & $\begin{array}{l}\text { Need for development of } \\
\text { individualized learning programs }\end{array}$ & 61.3 & 70.0 & 0.75 \\
\hline
\end{tabular}

Rank is based on response from both faculty and trainee. 


\begin{tabular}{|c|c|c|c|c|}
\hline \multicolumn{5}{|c|}{$\begin{array}{l}\text { Supplementary Table 1. Constructs and included items used for validity and reliability } \\
\text { testing }\end{array}$} \\
\hline Construct & Item & Mean & SD & $\mathbf{n}$ \\
\hline \multirow[t]{4}{*}{ Teaching } & & 3.44 & 0.87 & 73 \\
\hline & CBD will improve my teaching of residents & 3.45 & 0.91 & 73 \\
\hline & CBD will improve my role as a teacher & 3.44 & 0.88 & 73 \\
\hline & $\begin{array}{l}\text { CBD helps identify residents who require extra } \\
\text { assistance }\end{array}$ & 3.77 & 0.97 & 73 \\
\hline \multirow[t]{5}{*}{ Assessment } & & 3.83 & 0.78 & 73 \\
\hline & CBD will improve my feedback to residents & 4.19 & 0.79 & 73 \\
\hline & $\begin{array}{l}\text { CBD will improve my ability to identify specific } \\
\text { areas in need of improvement for resident } \\
\text { feedback }\end{array}$ & 3.86 & 0.93 & 73 \\
\hline & CBD will improve my evaluation of residents & 3.77 & 1.01 & 73 \\
\hline & $\begin{array}{l}\text { CBD makes my institution more accountable for } \\
\text { our graduates }\end{array}$ & 3.47 & 1.09 & 72 \\
\hline \multirow[t]{5}{*}{ Readiness } & 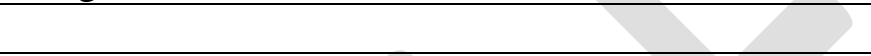 & 3.51 & 0.80 & 72 \\
\hline & $\begin{array}{l}\text { I am comfortable with my current knowledge of } \\
\text { CBD }\end{array}$ & 3.64 & 0.98 & 72 \\
\hline & $\begin{array}{l}\text { I received or will receive adequate training prior to } \\
\text { the implementation of CBD }\end{array}$ & 3.76 & 0.87 & 68 \\
\hline & $\begin{array}{l}\text { I am comfortable with the implementation process } \\
\text { of CBD }\end{array}$ & 3.13 & 1.19 & 70 \\
\hline & $\begin{array}{l}\text { My program is/was prepared for the transition into } \\
\text { CBD }\end{array}$ & 3.59 & 0.93 & 69 \\
\hline \multirow[t]{4}{*}{ Influence } & & 2.86 & 0.90 & 72 \\
\hline & $\begin{array}{l}\text { CBD will have a positive influence on my } \\
\text { academic practice }\end{array}$ & 3.04 & 1.04 & 70 \\
\hline & $\begin{array}{l}\text { CBD will have a positive influence on my clinical } \\
\text { practice (output) }\end{array}$ & 2.60 & 1.01 & 70 \\
\hline & CBD will have a positive influence on patient care & 2.90 & 0.98 & 60 \\
\hline Time & CBD increases staff time commitment to residents & 4.29 & 0.79 & 73 \\
\hline
\end{tabular}

Likert scale: 5 - Strongly agree and 1 - Strongly disagree. SD: standard deviation. 


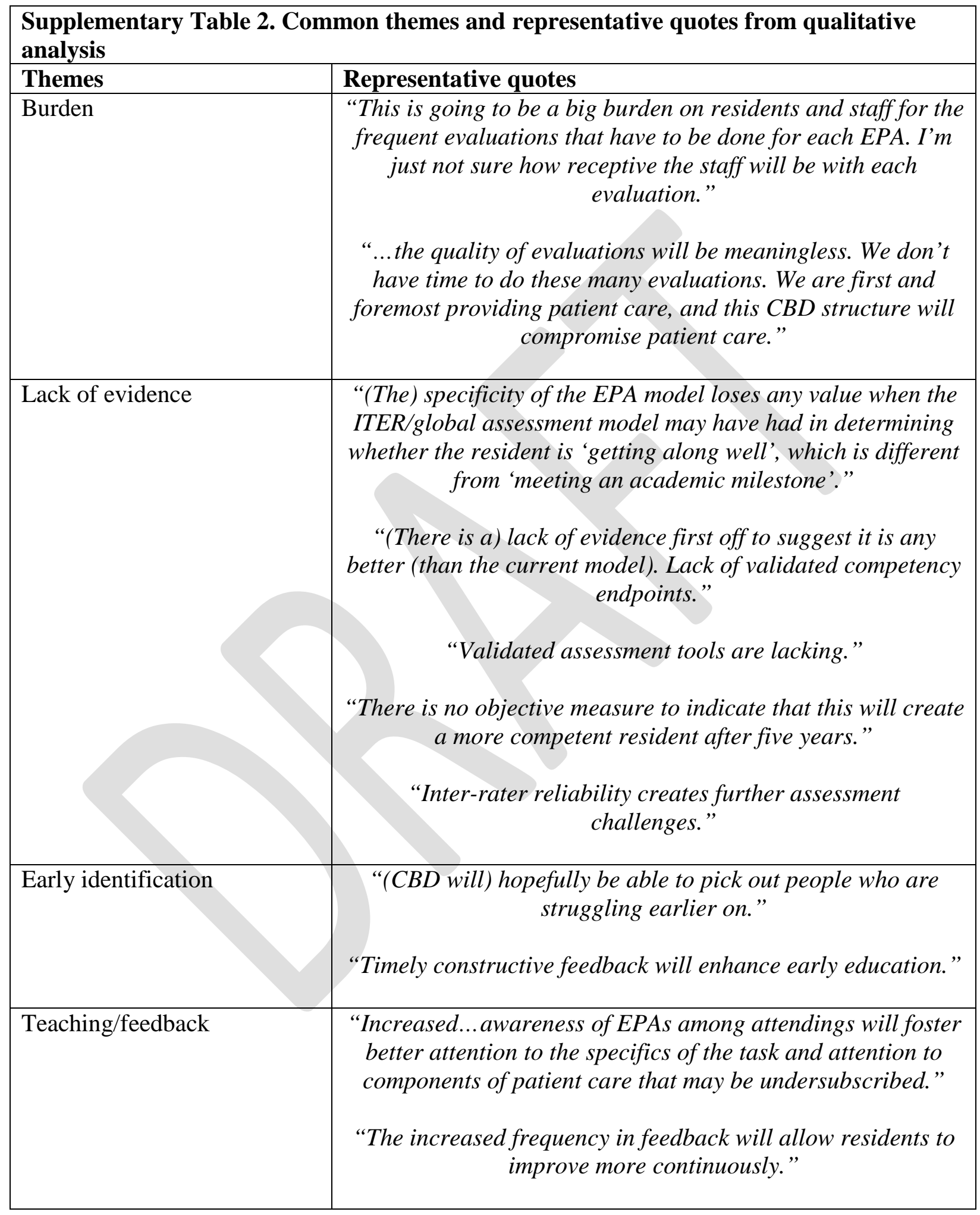


Q1.1. What is your status?

Resident/Fellow

Faculty

Q1.2. How many years of practice have you been in?

$0-5$ years

6-10 years

11-15 years

16-20 years

$>20$ years

Not applicable

Q1.3. What is your PGY level?

PGY-1

PGY-2

PGY-3

PGY-4

PGY-5

PGY-6

Postgraduate Fellow

Q33. Are you currently in a competency-based medical education stream, e.g. Competence by Design (CBD)?

Yes

No

Prefer not to say

Q1.4. What is your gender? 
Q1.5. What is your institutional name?

Western University

Q1.6. Are you currently a member of the Competence Committee?

Yes

No

Q1.7. Are you currently a member of your department/division's Residency Program/Training Committee?

Yes

No

\section{Perceptions of CBD}

\section{Q2.1. MEDICAL EDUCATION}

Please choose the statement that most accurately describes your opinion:

"CBD improved or will improve..."

\begin{tabular}{|c|c|c|c|c|c|c|}
\hline & $\begin{array}{l}\text { Strongly } \\
\text { Disagree }\end{array}$ & Disagree & $\begin{array}{c}\text { Neither } \\
\text { Disagree or } \\
\text { Agree }\end{array}$ & Agree & $\begin{array}{l}\text { Strongly } \\
\text { Agree }\end{array}$ & $\begin{array}{c}\text { Not } \\
\text { Applicable }\end{array}$ \\
\hline My teaching of residents & $\bigcirc$ & $\bigcirc$ & $\bigcirc$ & $\bigcirc$ & $\bigcirc$ & $\bigcirc$ \\
\hline My role as a teacher & $\bigcirc$ & $\bigcirc$ & $\bigcirc$ & $\bigcirc$ & $\bigcirc$ & $\bigcirc$ \\
\hline My feedback to residents & $\bigcirc$ & $\bigcirc$ & $\bigcirc$ & $\bigcirc$ & O & $\bigcirc$ \\
\hline
\end{tabular}

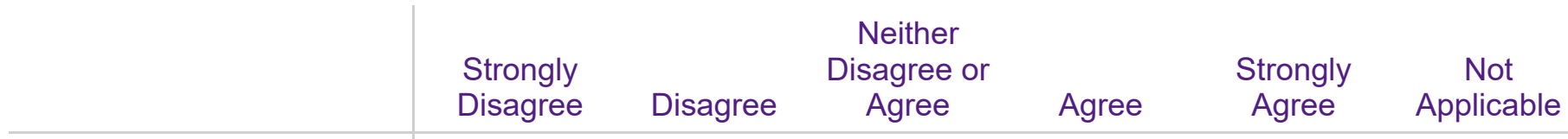

My ability to identify specific areas in need of improvement for resident feedback

My evaluation of residents

\section{Q28. MEDICAL EDUCATION}

Please choose the statement that most accurately describes your opinion: 
Neither

\begin{tabular}{|c|c|c|c|c|c|c|}
\hline & $\begin{array}{l}\text { Strongly } \\
\text { Disagree }\end{array}$ & Disagree & $\begin{array}{c}\text { Neither } \\
\text { Disagree or } \\
\text { Agree }\end{array}$ & Agree & $\begin{array}{c}\text { Strongly } \\
\text { Agree }\end{array}$ & $\begin{array}{c}\text { Not } \\
\text { Applicable }\end{array}$ \\
\hline $\begin{array}{l}\text { Staff teaching of } \\
\text { residents }\end{array}$ & $\bigcirc$ & $\bigcirc$ & $\bigcirc$ & $\bigcirc$ & $\bigcirc$ & $\bigcirc$ \\
\hline Staff role as a teacher & $\bigcirc$ & $\bigcirc$ & $\bigcirc$ & $\bigcirc$ & $\bigcirc$ & $\bigcirc$ \\
\hline $\begin{array}{l}\text { Staff feedback to } \\
\text { residents }\end{array}$ & 0 & $\bigcirc$ & $\bigcirc$ & $\bigcirc$ & $\bigcirc$ & $\bigcirc$ \\
\hline
\end{tabular}

\begin{tabular}{l|ccccc} 
& $\begin{array}{c}\text { Neither } \\
\text { Strongly } \\
\text { Disagree }\end{array}$ & Disagree & $\begin{array}{c}\text { Disagree or } \\
\text { Agree }\end{array}$ & $\begin{array}{c}\text { Strongly } \\
\text { Agree }\end{array}$ & $\begin{array}{c}\text { Not } \\
\text { Applicable }\end{array}$ \\
\hline $\begin{array}{l}\text { Staff ability to identify } \\
\text { specific areas in need of } \\
\text { improvement for resident } \\
\text { feedback }\end{array}$ & 0 & 0 & & \\
$\begin{array}{l}\text { Staff evaluation of } \\
\text { residents }\end{array}$ & 0 & & & & \\
\end{tabular}

\section{Q2.2. MEDICAL EDUCATION}

Please choose the statement that most accurately describes your opinion:

\begin{tabular}{|c|c|c|c|c|c|c|}
\hline & $\begin{array}{l}\text { Strongly } \\
\text { Disagree }\end{array}$ & Disagree & $\begin{array}{l}\text { Neither } \\
\text { Disagree or } \\
\text { Agree }\end{array}$ & Agree & $\begin{array}{l}\text { Strongly } \\
\text { Agree }\end{array}$ & $\begin{array}{c}\text { Not } \\
\text { Applicable }\end{array}$ \\
\hline $\begin{array}{l}\text { I am comfortable with my } \\
\text { current knowledge of } \\
\text { CBD }\end{array}$ & $\bigcirc$ & $\bigcirc$ & 0 & $\bigcirc$ & 0 & $\bigcirc$ \\
\hline $\begin{array}{l}\text { CBD makes my } \\
\text { institution more } \\
\text { accountable for our } \\
\text { graduates }\end{array}$ & 0 & ○ & 0 & 0 & $\bigcirc$ & 0 \\
\hline
\end{tabular}

\begin{tabular}{l|ccccc} 
& $\begin{array}{c}\text { Neither } \\
\text { Disagree or } \\
\text { Agree }\end{array}$ & $\begin{array}{c}\text { Strongly } \\
\text { Disagree }\end{array}$ & Disagree & $\begin{array}{c}\text { Strongly } \\
\text { Agree }\end{array}$ & $\begin{array}{c}\text { Not } \\
\text { Applicable }\end{array}$ \\
\hline $\begin{array}{l}\text { CBD helps identify } \\
\text { residents who require } \\
\text { extra assistance }\end{array}$ & 0 & 0 & & \\
$\begin{array}{l}\text { CBD increases staff time } \\
\text { commitment to residents }\end{array}$ & 0 & 0 & 0 & 0
\end{tabular}

\section{Q2.3. IMPLEMENTATION}

Please choose the statement that most accurately describes your opinion:

Neither

Stronalv Disanree or
Stronaly Not 


\begin{tabular}{|c|c|c|c|c|c|c|}
\hline & & \multirow[b]{2}{*}{ Agree } & \multirow[b]{2}{*}{ Applicable } \\
\hline & Disagree & Disagree & Agree & Agree & & \\
\hline $\begin{array}{l}\text { I received or will receive } \\
\text { adequate training prior to } \\
\text { the implementation of } \\
\text { CBD }\end{array}$ & 0 & 0 & ○ & $\bigcirc$ & ○ & ○ \\
\hline $\begin{array}{l}\text { I am comfortable with the } \\
\text { implementation process } \\
\text { of CBD }\end{array}$ & O & ○ & O & O & ○ & 0 \\
\hline $\begin{array}{l}\text { My program is/was } \\
\text { prepared for the } \\
\text { transition into CBD }\end{array}$ & 0 & 0 & O & 0 & ○ & 0 \\
\hline
\end{tabular}

\section{Q2.4. INFLUENCE OF CBD}

Please choose the statement that most accurately describes your opinion:

"CBD has or will have a positive influence on..."

\begin{tabular}{|c|c|c|c|c|c|c|}
\hline & $\begin{array}{l}\text { Strongly } \\
\text { Disagree }\end{array}$ & Disagree & $\begin{array}{c}\text { Neither } \\
\text { Disagree or } \\
\text { Agree }\end{array}$ & Agree & $\begin{array}{l}\text { Strongly } \\
\text { Agree }\end{array}$ & $\begin{array}{c}\text { Not } \\
\text { Applicable }\end{array}$ \\
\hline My academic practice & O & $\bigcirc$ & $\bigcirc$ & $\bigcirc$ & $\bigcirc$ & $\bigcirc$ \\
\hline $\begin{array}{l}\text { My clinical practice } \\
\text { (output) }\end{array}$ & $\bigcirc$ & $\bigcirc$ & $\bigcirc$ & $\bigcirc$ & $\bigcirc$ & $\bigcirc$ \\
\hline Patient care & $\bigcirc$ & $\bigcirc$ & $\bigcirc$ & $\bigcirc$ & $\bigcirc$ & O \\
\hline
\end{tabular}

\section{Favorability of CBD}

Q3.1.

How favourable are you towards Competence by Design (CBD) for postgraduate training in your program?
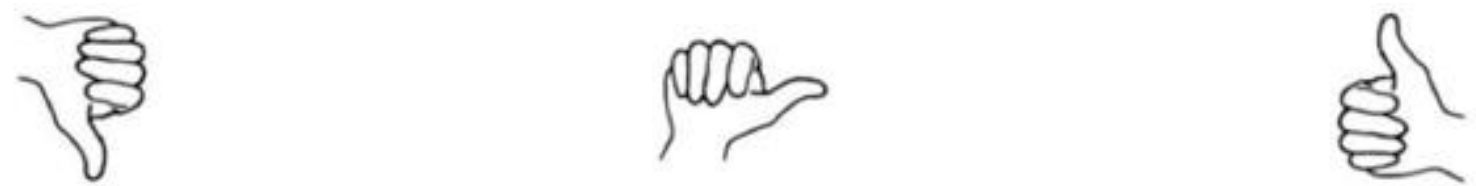

\section{0}

1

2

3

4

5

6

7

8

9

Favorability of CBD

\section{Perceived Benefits}

Q32. For the next set of questions, please drag-and-drop the "Item" from the left to the most appropriate response category on the right ("Benefit", "Not a Benefit", or "Unsure") that represents your views. 
Q4.1.

Identifying residents \& skill acquisition

In your opinion, what benefits have resulted or will result from CBD?

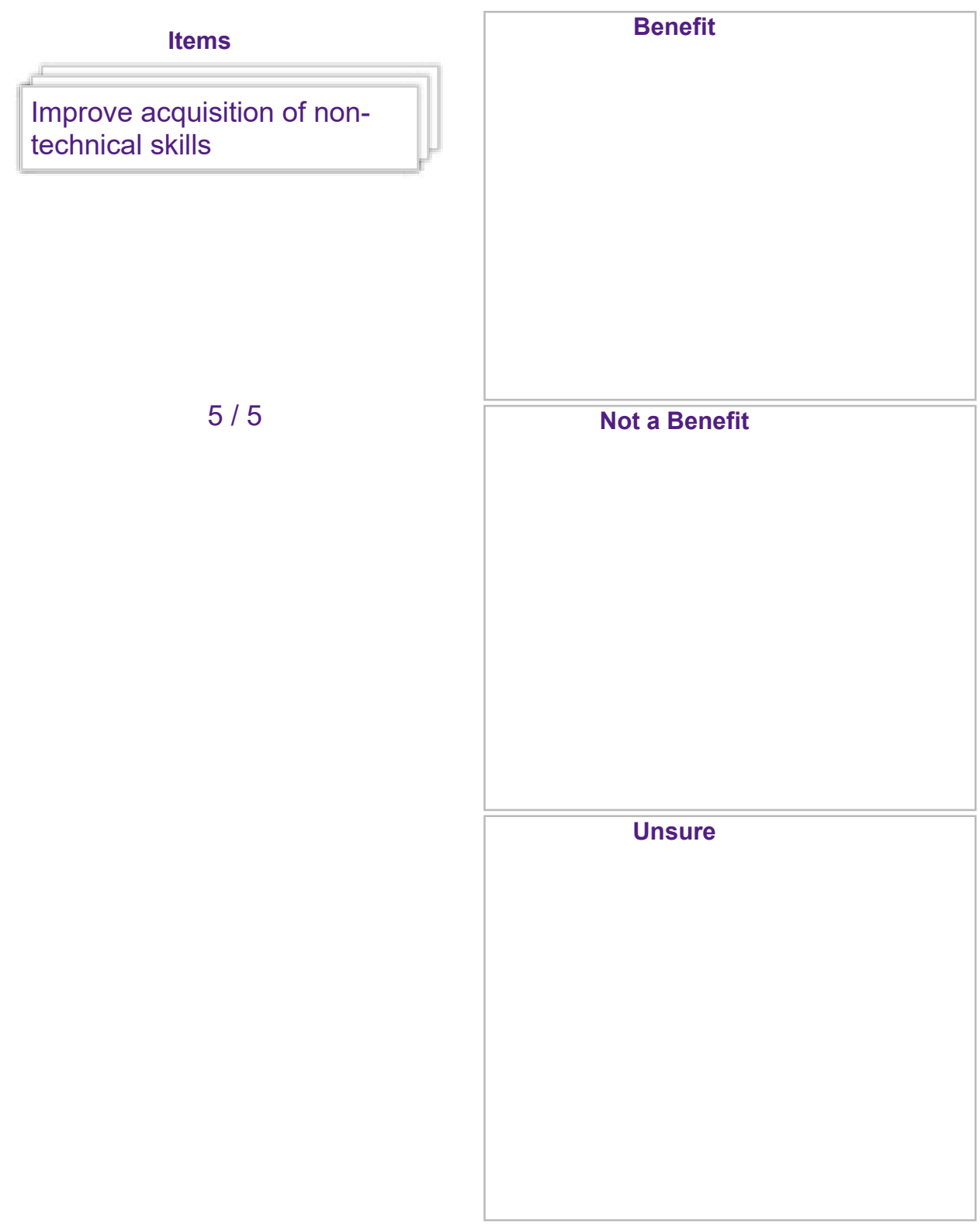

\section{Q4.2.}

\section{Faculty \& feedback}

In your opinion, what benefits have resulted or will result from CBD?

\begin{tabular}{|l|l|}
\hline \multicolumn{1}{|c|}{ Items } \\
Increase accountability of \\
faculty for resident education \\
competency level that \\
residents are expected to
\end{tabular}


$5 / 5$

\begin{tabular}{|l|}
\hline Not a Benefit \\
\hline Unsure \\
\hline \hline Und \\
\hline
\end{tabular}

Q4.4.

\section{Residents}

In your opinion, what benefits have resulted or will result from CBD?

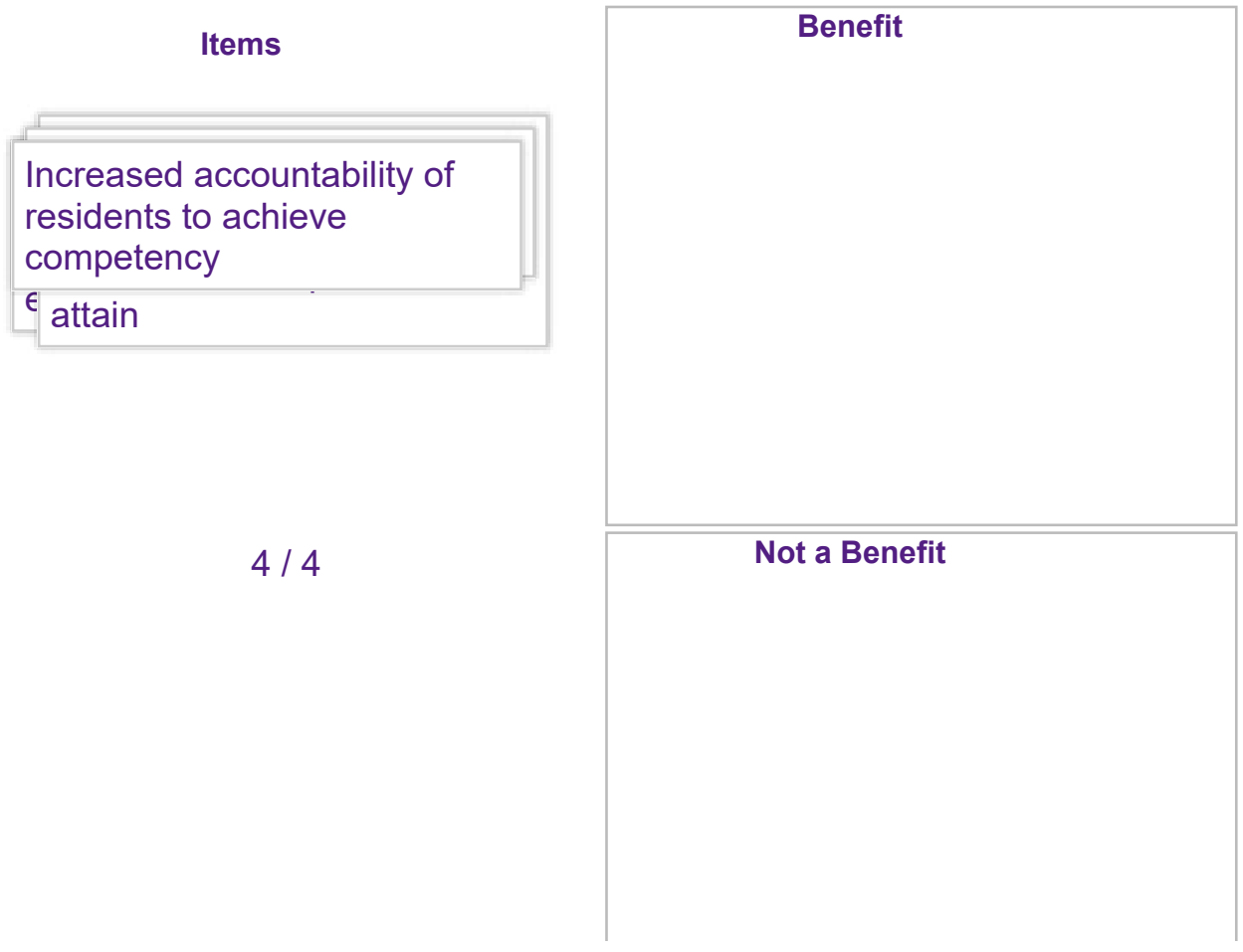




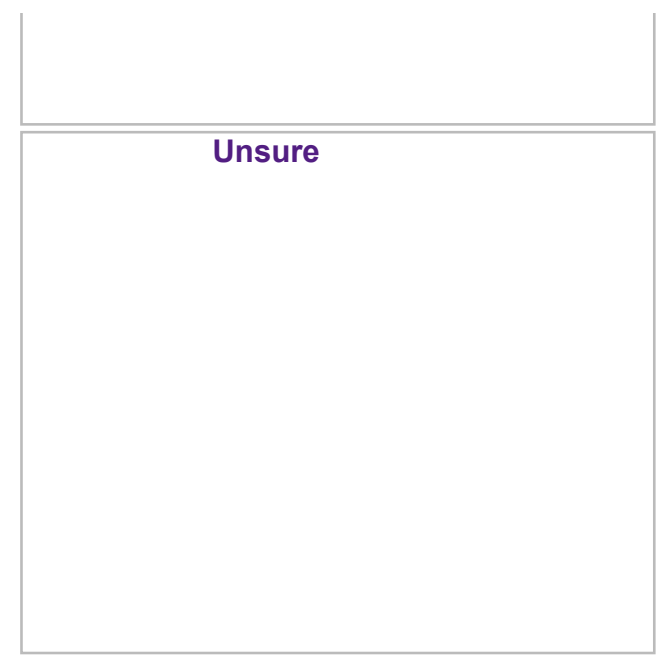

Q53.

Accuracy of evaluation \& graduates

In your opinion, what benefits have resulted or will result from CBD?

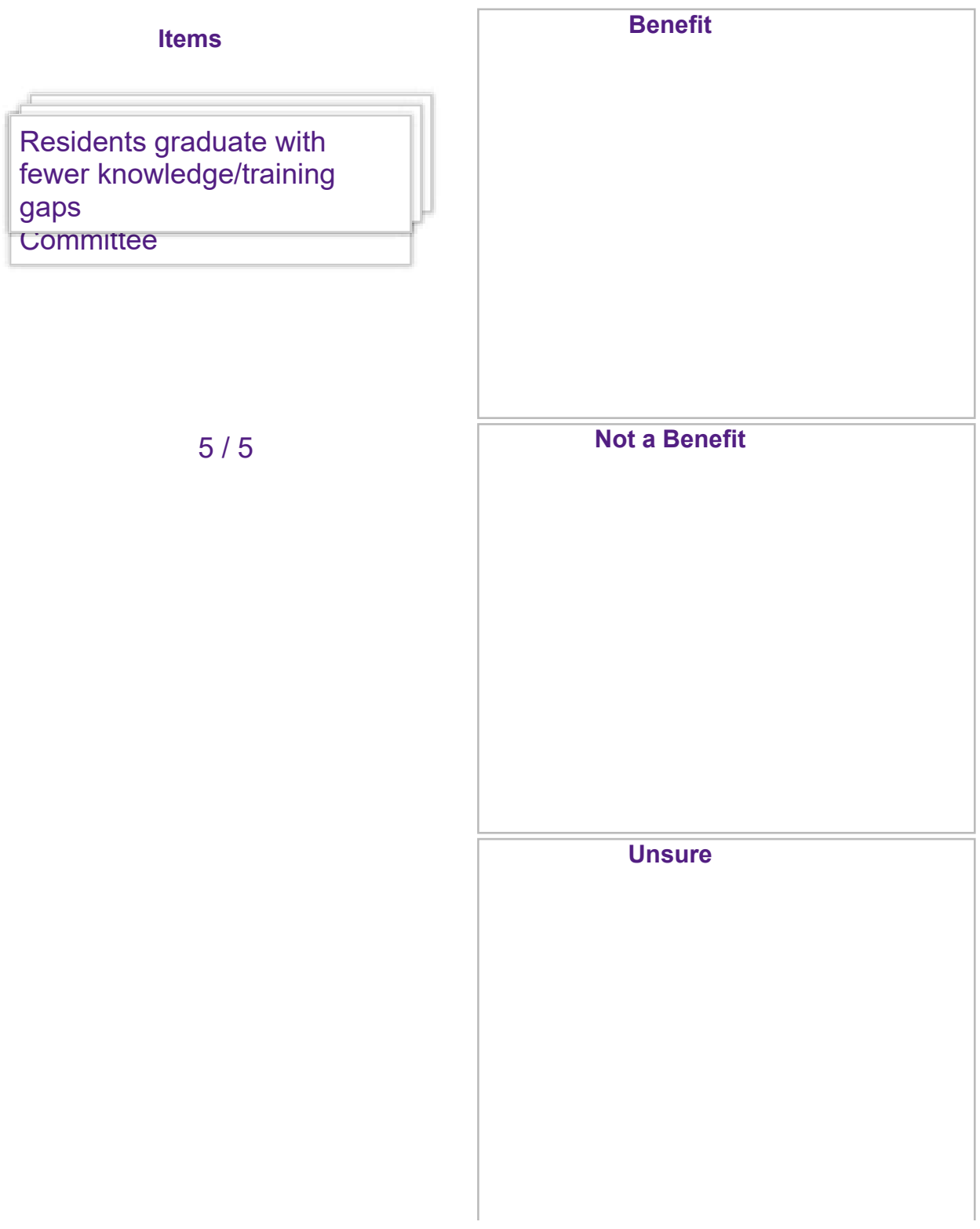


Q4.5.

Training program

In your opinion, what benefits have resulted or will result from CBD?
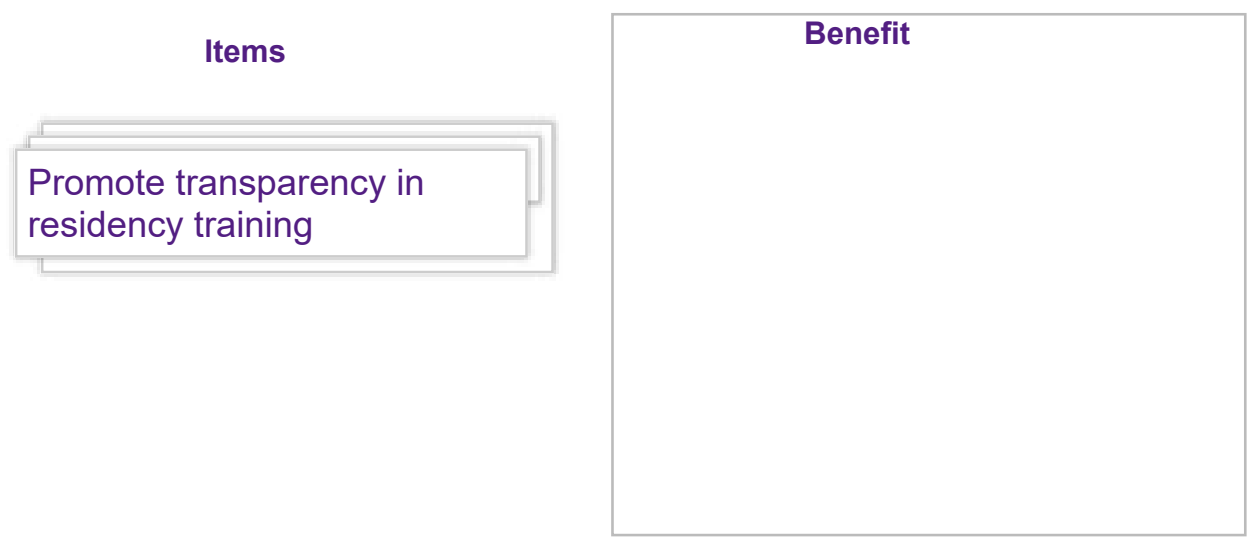

$3 / 3$

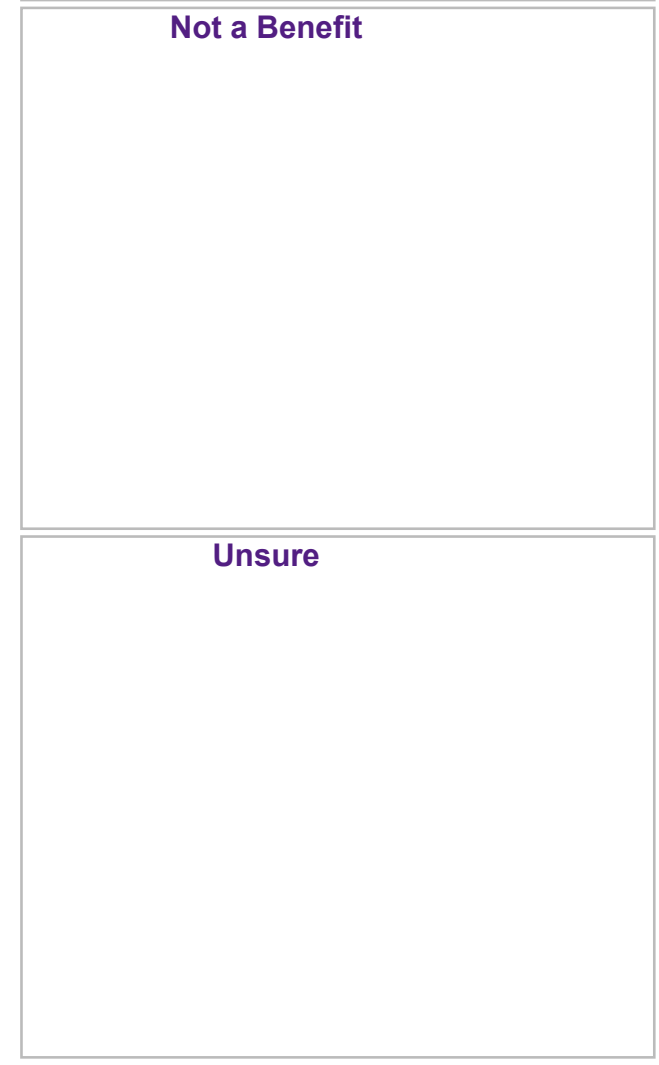

Q4.6.

Miscellaneous

In your opinion, what benefits have resulted or will result from CBD?

\begin{tabular}{|c|c|} 
Items & Benefit \\
Improved patient care &
\end{tabular}


$4 / 4$
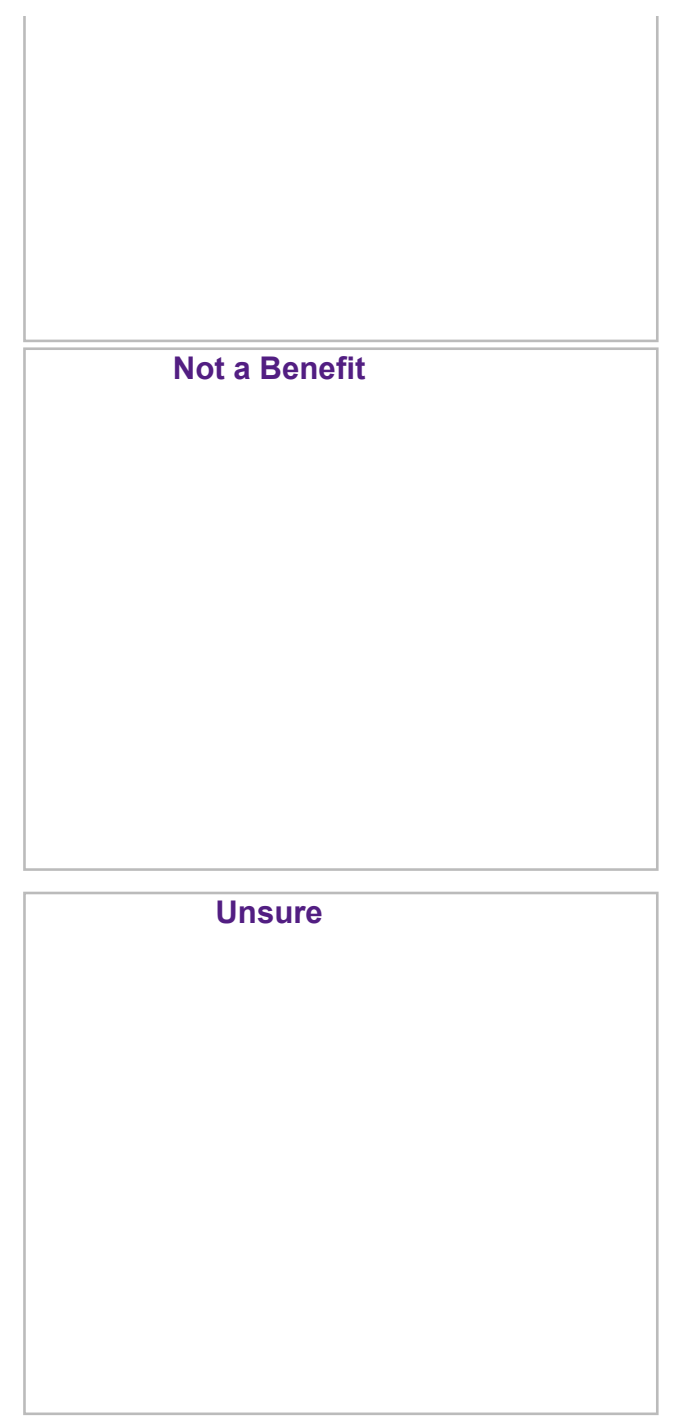

\section{Perceived Challenges}

Q5.1.

Faculty

In your opinion, what challenges have resulted or will result from CBD?

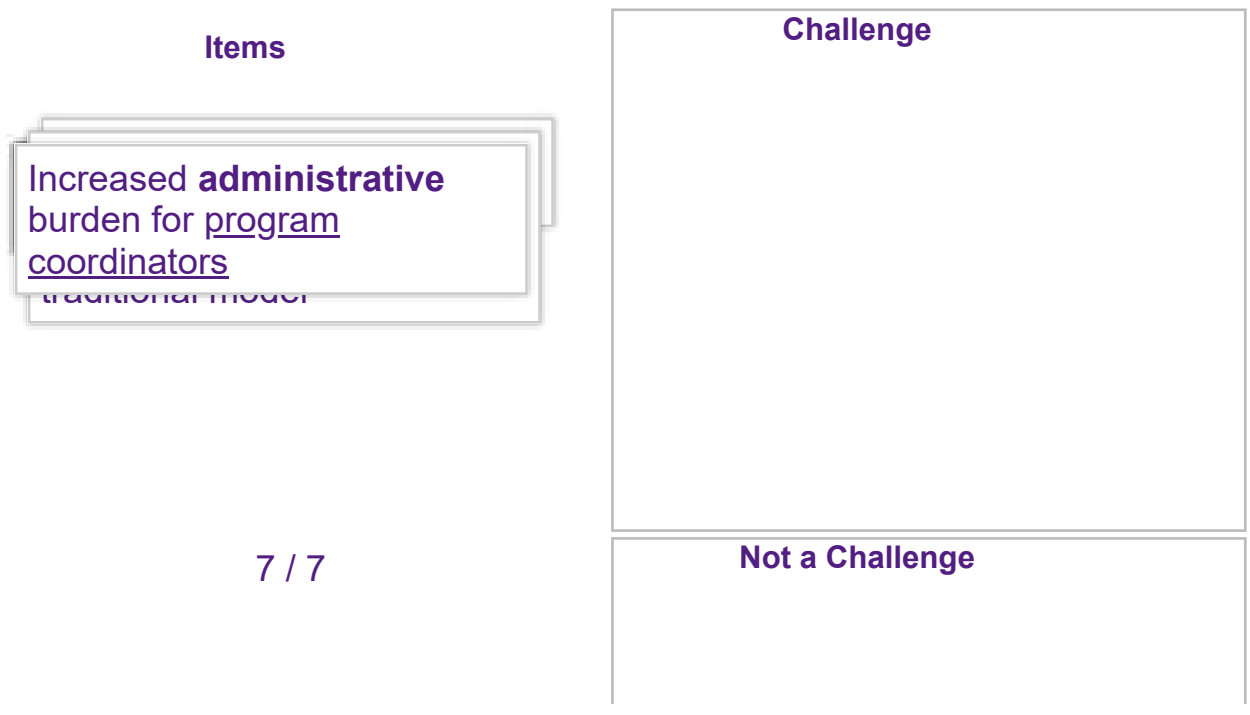




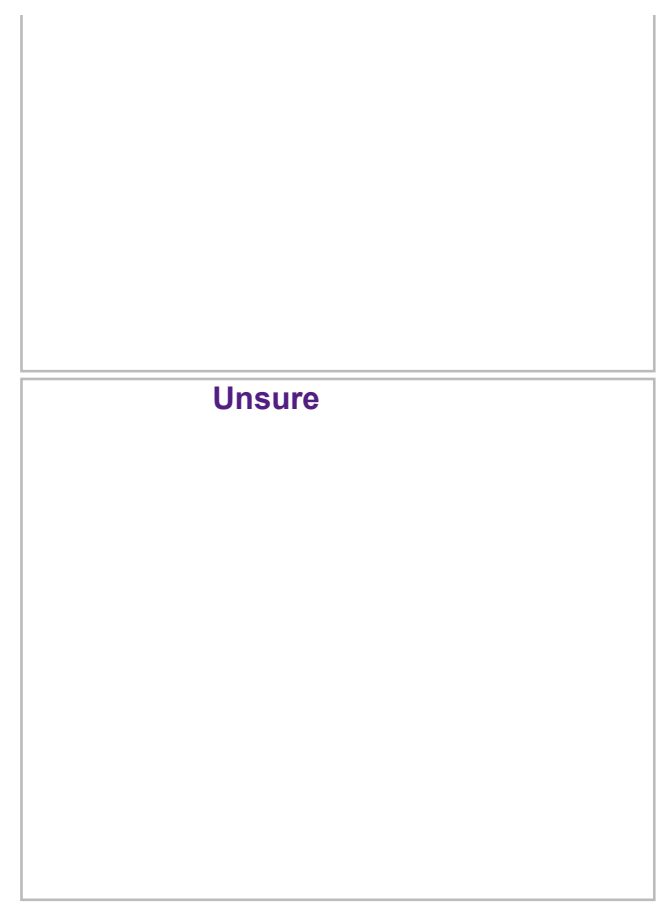

Q5.2.

Assessment

In your opinion, what challenges have resulted or will result from CBD?

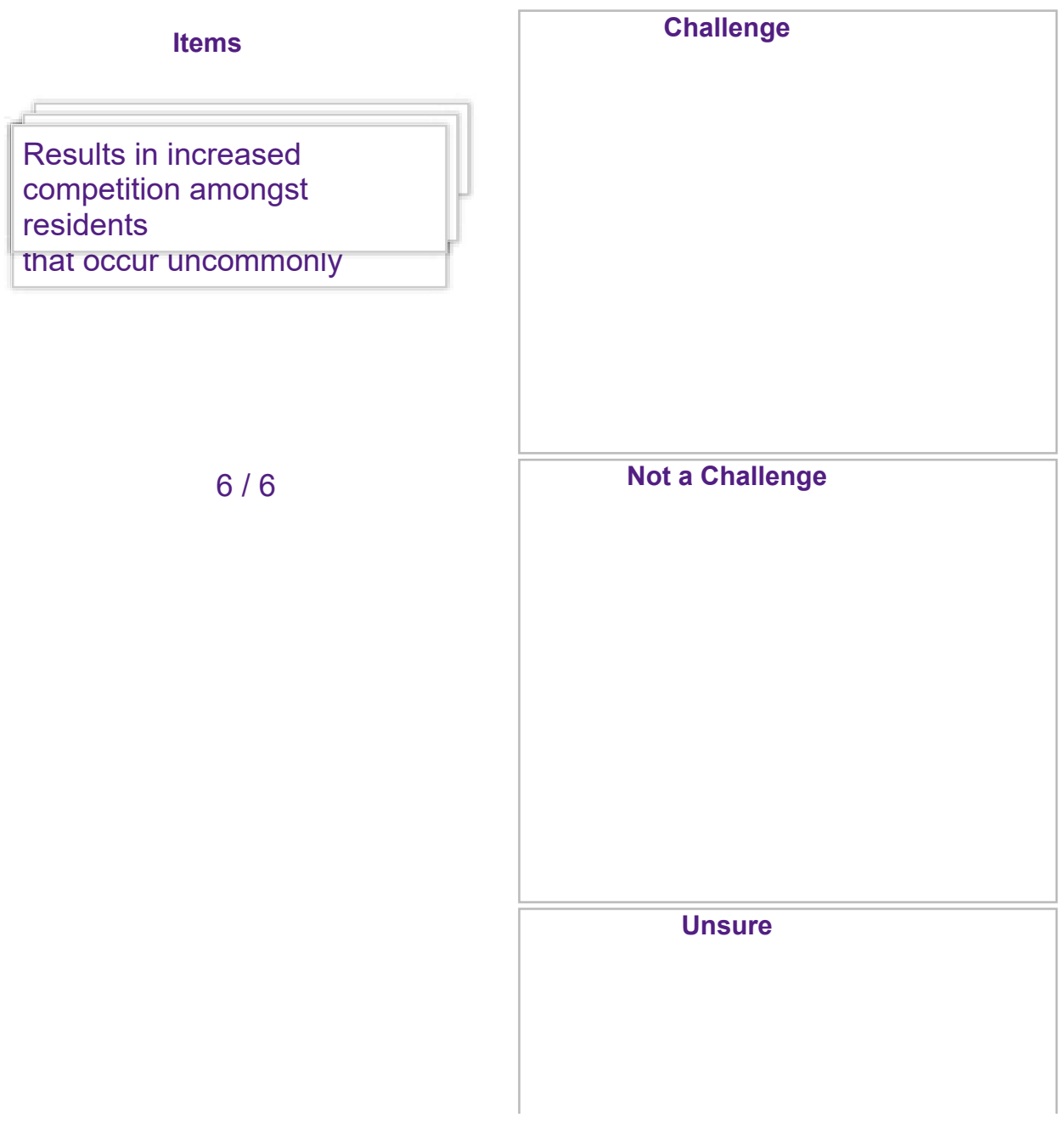


Q5.3.

\section{Training program}

In your opinion, what challenges have resulted or will result from CBD?

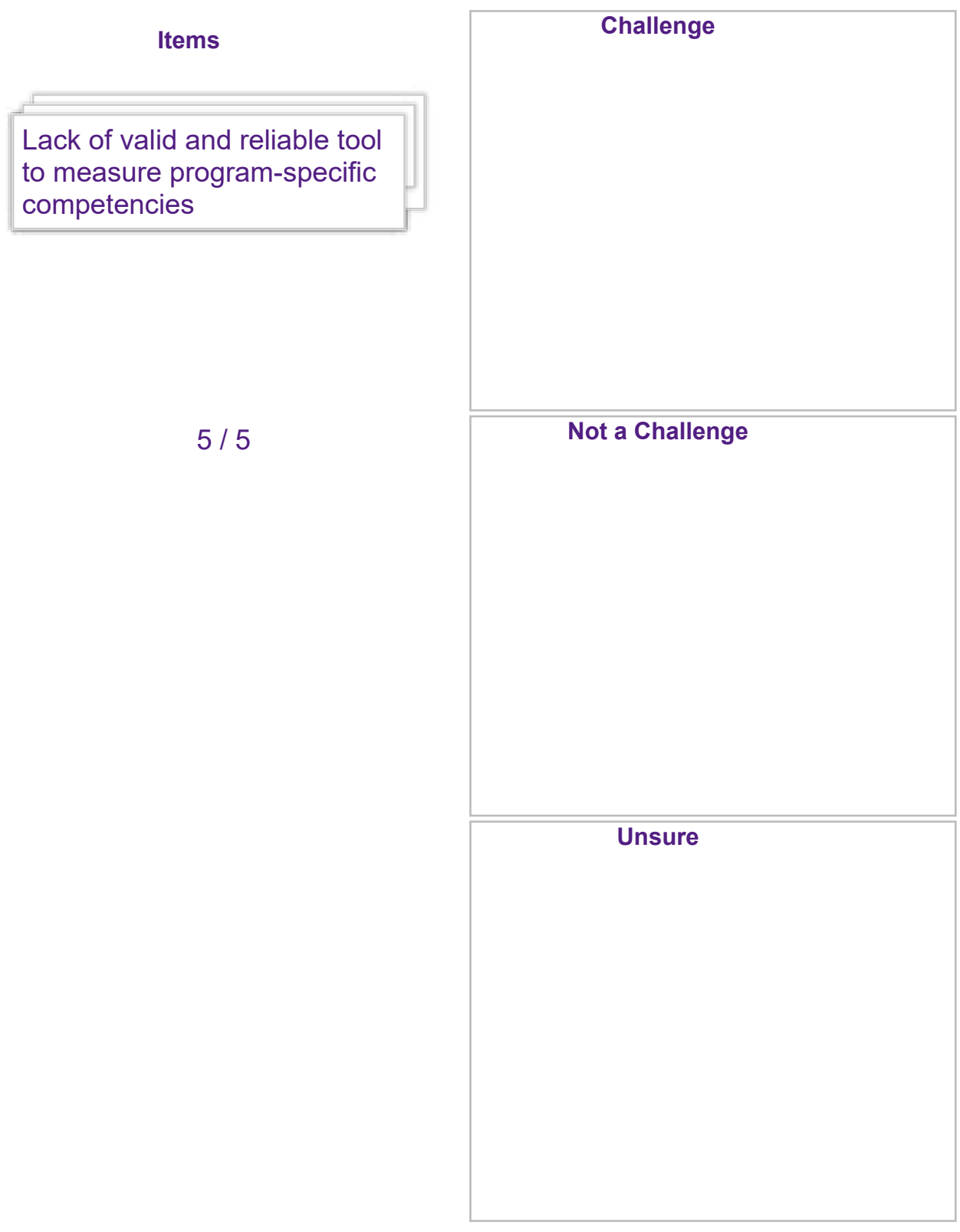

Q5.4.

\section{Residents}

In your opinion, what challenges have resulted or will result from CBD? 


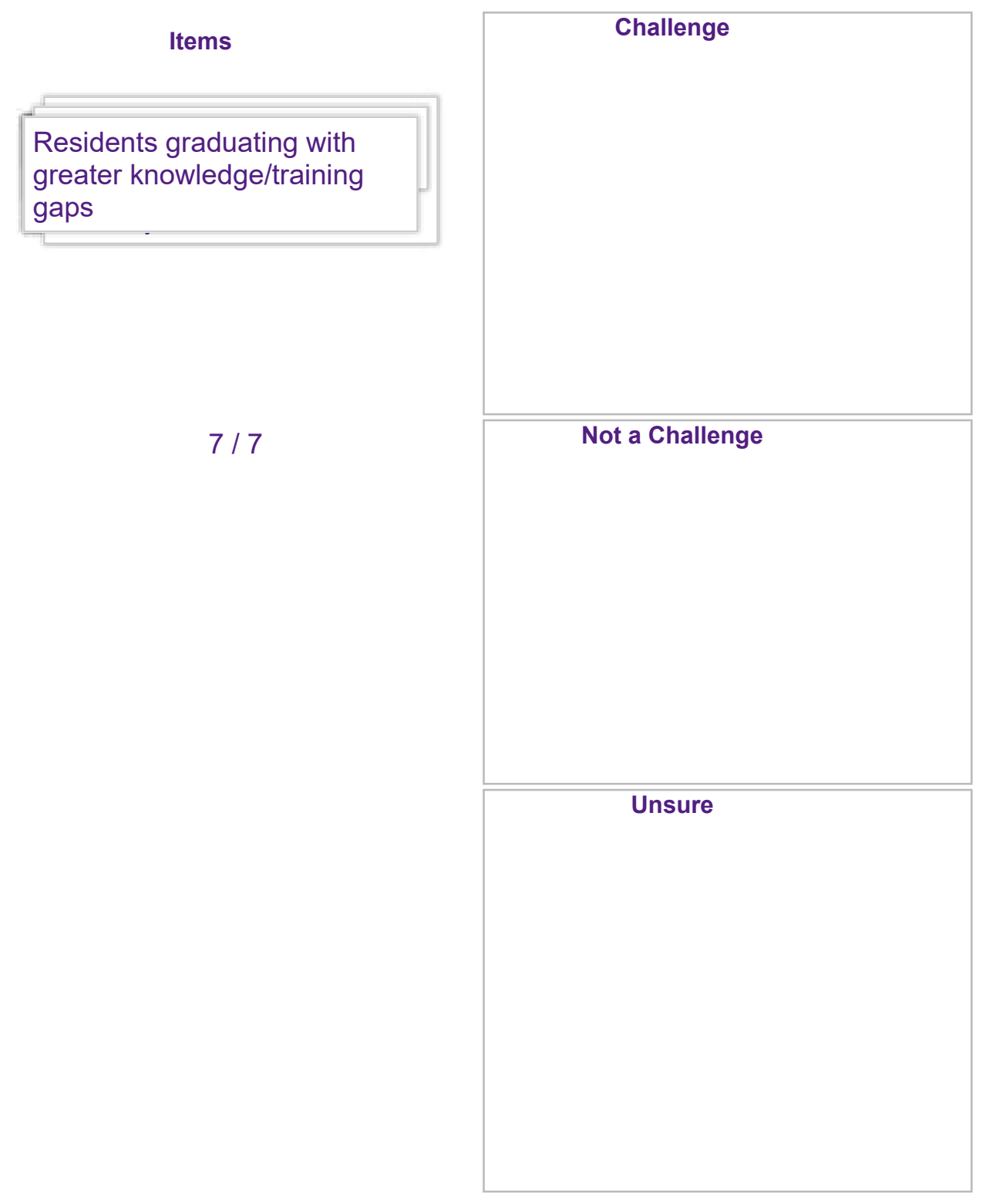

Q5.5.

Miscellaneous

In your opinion, what challenges have resulted or will result from CBD?

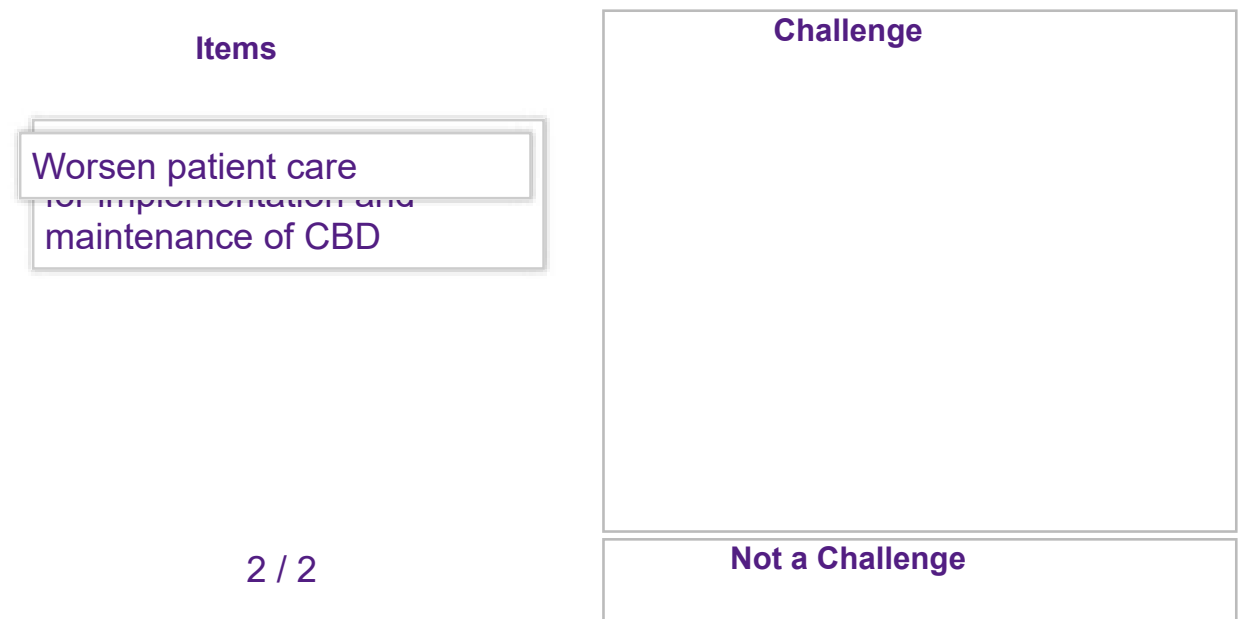




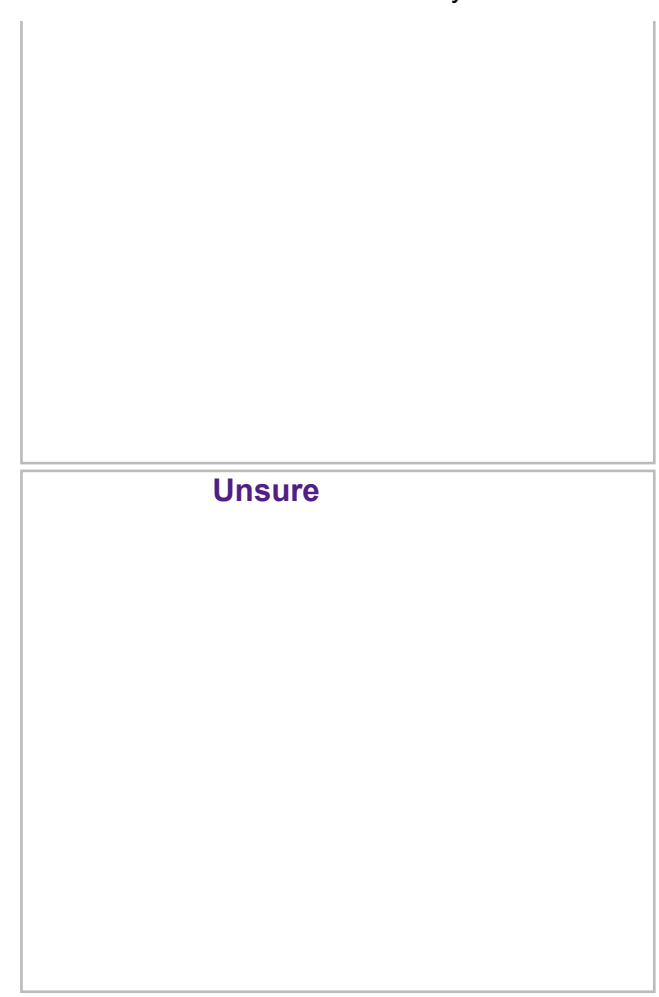

\section{Open-ended Questions Regarding CBD}

Q6.1.

What are you most concerned about regarding the transition to CBD?

Q6.2.

What benefits do you foresee (or have already seen) resulting from this transition and why (even if none)? 